\title{
Agricultural Policy and Political Governance in Nigeria: Fiscal Sociology and the Challenges of a Rent-Seeking Economy
}

\author{
Taiwo A. Olaiya \\ Department of Public Administration, Obafemi Awolowo University, Ile-Ife, Nigeria
}

\begin{abstract}
"the economic bleeding...[t]he spirit of a people...the deeds its policy may prepare...all this and more is written in fiscal history. He who knows how to listen to its message here discerns the thunder of world history more clearly than anywhere else" Joseph Alois Schumpeter, 1918.
\end{abstract}

\begin{abstract}
Despite the current financial crisis facing all levels of governments of Nigeria, virtually no efforts have been directed at the sociological analysis of the finances. The situation particularly begs for attention considering the dwindling agricultural status, focusing on cocoa, and the multiple socio-economic, political and cultural distortions embedded in its monolithic source of revenue. The literature is replete with the sociological analysis of pubic financial management. However, those analyses appear to be much more concentrated on the advanced than the developing economies. In this review article, we attempted a public economy discourse of developing economies, focusing on the deleterious interplays between the dominant oil income and agricultural outputs and how the duo has made Nigeria a rentier economy. With a critical review of integrated literature on the sociology of oil politics; the institutional and symbolic element of the tax-dependent economy; and the historical volatility of rentier economies; we critically drew a nexus between the current life-threatening revenue profile of Nigeria and her major, if not solitary, reliance on petrodollar as well as the socio-cultural manifestations. Like this, the essay advanced the significance of fiscal sociology as a veritable tool for constructing a theory about state finances.
\end{abstract}

DOI: $10.7176 / \mathrm{JESD} / 10-14-08$

Publication date:July $31^{\text {st }} 2020$

\section{Introduction}

In recent time, Nigeria, like other oil-dependent nations, witnessed significant downturns in her revenue profile due mainly to the volatile global price of the natural resources. Budget benchmarks have been utterly affected, and projects and programmes designed to meet the basic needs of the citizens have had to be readjusted, if not abandoned, mid-term. Like every other resource-dependent nation, the price volatility has not only affected Nigeria's ability to meet basic needs to the citizens, the citizens have also reacted in terms of low public acceptance of the governments they hitherto elected by popular votes. Sometimes, the critical finances have led to various social misgivings, like unrest, violence and industrial crises as experienced in 2012 due to the removal of petrol subsidy. The Federal Ministry of Budget and Planning (FMBP) reported that Nigeria experienced acute fiscal anxiety in 2014 following the fall of the crude oil price by more than $40 \%$. Subsequently, the nation experienced an unprecedented budget shortage in 2015 despite her conservative (research-informed) adoption of $\$ 65$ per barrel benchmark (FMBP, 2016). From the records of "Export crude oil production and price" published by the Central Bank of Nigeria (CBN) from 2006 to 2019 (CBN, 2020a), the benchmarks have significantly reduced the budget proposals and generated heated debates as to the continued credibility of reliance on oil revenue. While crude oil production and export remain flat, the price fluctuates in no small ways and fostering volatility and inevitable deviations from budget benchmarks (see figure 1). With the current COVID-19 pandemic ravaging the world and causing Nigeria's crude oil price to fall to a record low price of \$25 per barrel in March 2020 (CBN, 2020b), the overall effect on budgeting, development plans, and provision of amenities to the citizens, who are already strained by years of poor governance, remains exacerbated. 


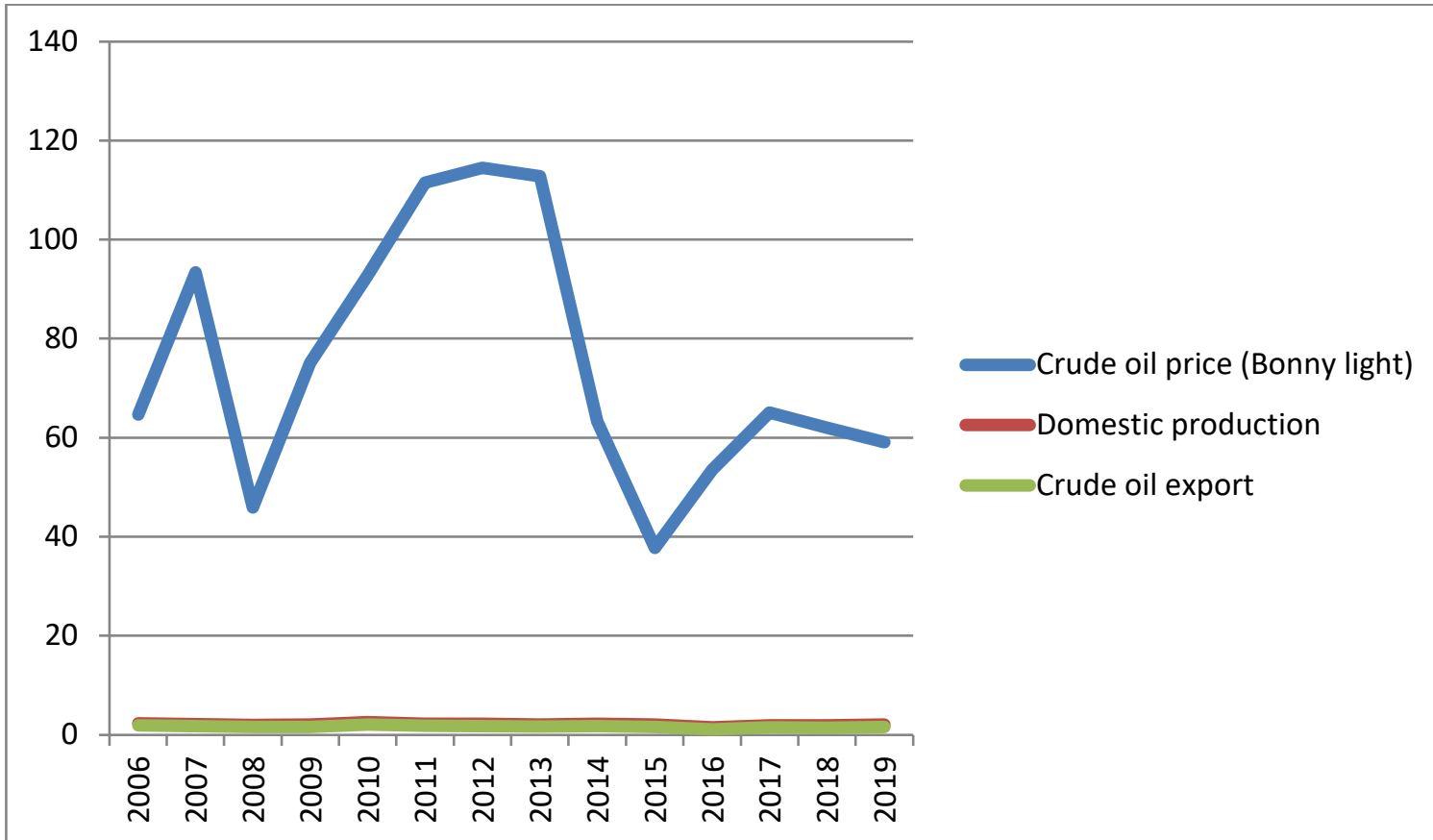

Figure 1: Showing the oil production/export and volatility of oil revenue

Source: The Central Bank of Nigeria (CBN). See https://www.cbn.gov.ng/rates/crudeoil.asp?year=2019

Various scholarly works have examined the causes and consequences of the volatile and of shrunken revenue, especially on how the unsavoury situation has impacted adversely on government ability to accomplish its statutory and social responsibilities. Available ones include, but not limited to Ademola (2019), Ukiwo (2020), Zadawa and Omran (2020) who argued that the current dearth of government revenue is a result of its monolithic economy. For Abiola and Okafor $(2013$, p. 1) the crisis is that of failure to model for benchmarking price in budget proposals "to enhance the predictability of policy and promote macroeconomic stability". The phenomenon that surrounds the public finance of a nation is undoubtedly beyond the arithmetic of revenue and expenditure balances. In critical terms, the financial pendulum that afflicts and soothes her, as the case may be, can only be more understood when examined "within their historical content and evolution and are properly placed in their sociological context" (Andic \& Andic, 1985). Various studies have also investigated the causes and consequences of the monolithic nature of the Nigerian public finance. Due to overdependence on oil revenue and the attendant lack of transparency and accountability, Bandura and Hammond (2018, p. 2) and Mahler (2010, p. 5) respectively tagged Nigeria a "textbook example of the natural resource curse: an economy heavily dependent on a few commodities that provide the bulk of export earnings and government revenues" and a "prime example of the resource curse". Oyibo, Zakari and Rekwot (2013) argued that Nigeria's agriculture has continued to suffer decline over the years due to inadequate budgetary allocation. The lapses relate effectively to oil revenue that shifted the focus away from agriculture - a once blossom source of income before the discovery of oil in the late 1950s. Ukiwo (2020, p. 311) addressed the crisis more succinctly. According to the writer, the jumbo revenue from oil shot Nigeria into a sudden global reckoning and "accounted for not less than 80 per cent of public revenues and a minimum of 90 per cent of the country's foreign exchange".

Nevertheless, the same commodity derailed Nigeria from a booming agricultural economy into "a rentier State since the 1970s" and weakened the structure of sustainable economic posture that was apparent at independence (Ukiwo, 2020, p. 311). Spinoza and Vallee (2008) likened Nigeria to potential shipwreck for the continued overdependence on oil revenue. Other writers have demonstrated how oil revenue has led to political and economic crises of all sorts, and protracted internecine crisis in the Niger Delta Region, the Northeast, the Southwest, Southeast and other parts of Nigeria (Olaiya, 2016; Sayne \& Hruby, 2016; Nwasomba \& Alumona, 2013; Genova \& Falola, 2003; Mahler, 2010; Gordon, 2011; Kumar, 2005; Akhaine, 2010; Nwajiaku-Dahou, 2012).

Despite, and despite the current financial crisis facing all levels of governments of Nigeria, virtually no efforts have been directed at the sociological analysis of the finances particularly in regards to the dwindling agricultural status and the multiple socio-economic, political and cultural distortions embedded in its monolithic source of revenue. The literature is replete with the sociological analysis of pubic financial management. However, those analyses, as the article reveals, appear to be concentrated on advanced democracies, In this review article, we focused on the deleterious interplays between the dominant oil income and agricultural outputs and how the duo has made Nigeria a rentier economy. With a critical review of integrated literature on the sociology of oil politics; 
the institutional and symbolic element of the tax-dependent economy; and the historical volatility in rentier economy; we critically drew a nexus between the current life-threatening revenue profile of Nigeria and her major, if not solitary, reliance on petrodollar as well as the socio-cultural manifestations. Like this, the essay advanced the significance of fiscal sociology as a veritable tool for constructing a theory about state finances.

\section{Conceptual notes on fiscal sociology and theoretical underpinning}

Fiscal sociology interrogates the critical link between the financial direction of a state and her governance. There is no doubt that fiscal sociology as an offshoot of social science discipline has not suffered from the quality scholarly debate (Maetin \& Prasad, 2014). Contrary to what Campbell (2009:256) tagged lack of "coherent research area", the linkages between revenue source have come of age. Incidentally, Campbell (2009) admitted that "influential theorist, such as Max Weber and Joseph Schumpeter, called for and did research on the subject" as far back as the early decades of the twentieth century. Also, the footpaths of historians, sociologists and political scientists have been felt in the subject (Campbell, 1993). Andic and Andic (1985) argued that the subject matter that came to be tagged by Schumpeter in early $20^{\text {th }}$ century had been unmistakably articulated in the works of Ibn Khaldun, a $14^{\text {th }}$ Century social scientist and historical philosopher. Fiscal sociology may therefore not be a popular jingo as some scholars have observed, the subject has had the benefit of long and rich historical antecedents (Mumford, 2008; McClure, 2003; Campbell, 2009, Olaiya, 2016). In the recent time, the subject has attracted several scholarships across the disciplines of social sciences and humanities including the socio-legal, constitutional, neoclassical and neoliberal studies, and welfare statism (Campbell, 1993; Mumford, 2008, Moller, 2007).

The analytical technique of taxation and public finance, known as "fiscal Sociology", developed by sociologists around early decades of the $20^{\text {th }}$ century is the overall conceptual approaches to this study. Rudolph Goldscheid and Joseph Schumpeter developed the concept to address the public financial crisis at the time. Goldscheid and Schumpeter's thesis centres principally on abandoning revenue source(s) that prone to "pillage and plunder", such as oil and minerals, were for taxes to foster the emergence and flounder of the essential characteristics of governance and market in a state (Mumford, 2008). The proponents of fiscal sociology could, therefore, be said to have argued that "the roots of modern governmental conflict and decision-making can be traced back to the inception of a country's tax system" (Mumford, 2008, p. 221). There is no gainsaying, therefore, that the core of this sociological theory is to showcase how tax revenue towers above other sources as a sustainable means for public finance and good governance.

Not mainly being the pioneer of the thinking around which the core values of fiscal sociology is built, the slender popularity enjoyed by the subject today is perhaps attributable to Joseph Schumpeter. Schumpeter is famous for observing that "the thunder of world history can be heard best in the realm of public finance" (Mumford 2008). According to Schumpeter, the fate of a nation moves back and forth as the revenue profile changes. The change of such revenue profile goes beyond a mere adoption of one revenue source as a replacement for another; it portends a dramatic turn of event in all fundamental ways. The change reflects, among others, in structural recomposition of the economic formations and actors, fiscal and monetary cultures, citizens/governance direction of the state. Goldscheid's argument that the quest for taxes has resulted in confrontations from time immemorial has been reinforced by contemporary writers like Mumford (2008) and Moller (2007).

In "Wherefore the Liberal State? Post-Soviet Democratic Blues and Lessons from Fiscal Sociology", Moller (2007) explained how fiscal sociology_or Finanzsoziologie in German-started with striking historical antecedents dating back to the 'Mitteleuropa' period in the first 30 years of the twentieth century. According to the author, the Austrian academic Rudolf Goldscheid invented the phrase before Joseph Schumpeter developed it in his classic essay "The Crisis of the Tax State". It was Schumpeter who advocated that the fate of any nation lies in his fiscal history (Moller, 2007). The simplest version of the sociological argument, as Moller (2007, 302) rightly pointed out, presupposes that "the character of the state depends upon the character of the public finances". With regards to this article, a critical hypothesis could be deciphered: that a strong historical relationship - most probably causal but somewhat symptomatic - exists between the sustainability of effective taxation and the revitalisation of the burden of governance. Quoting John Carteret, a great seventeenth-century English statesman, Moller (2007, p. 4) elucidated: "the Security of our Liberties is not in the Laws but by the Purse being in the Hands of the People".

Three major theoretical frameworks exist in the world today, which experts believe will ensure national economic prosperity and reduce poverty. These are the adoption of open economies or trade liberalisation; reliance on the market in the allocation of resources and determination of prices; and enthronement of democratic rules with the ultimate focus on the masses. The first emphasises the advantage of interacting with other countries of the world, as propounded in David Ricardo's principle of comparative advantage. The second axiom relies on the efficiency of the market forces in the allocation of scarce resources and the determination of prices. In contrast, the third relies on democracy as an offshoot of good governance.

The basis of trade between countries and regions often referred to as international trade traced its root to the works of the earliest economists like David Ricardo, John Stuart Mill, Cairnes and Bastable. They argued that 
countries would engage in trade because of the principle of comparative advantage (Jhingan, 2008). These Economists propounded that, for reasons of geographical advantage and labour efficiency, the cost of production can be minimised in one country than the other. In theory, therefore, countries are encouraged to engage in trade if there are advantages of comparative advantage. Despite its beauty in explaining the basis of international trade, neoclassical Economists criticised the Comparative Advantage theory in several ways. Consequently, Bertin Ohlin reformulated the theory of comparative advantage in 1933 following Eli Hecksher argument that countries engage in trade because of differences in factor endowment. The theory was named after the two great Economists and christened the Hecksher-Ohlin theory.

The Hecksher-Ohlin theory states that a reasonable consideration in optimum production of a particular product in a given country depends on how much of the relevant factor supplies are readily available. Accordingly, the theory explained that countries and regions are differently blessed: while some are endowed in the capital, others have labour and raw material in relative abundance. To maximise a country's output, therefore, the country only needs to specialise in the production of the material for which it possesses relative advantage. The totality of it all is for the government to identify this area of comparative advantage and adequately channel the production line of the country in that direction. The assumption is that such precise bearing on the part of the government would not only breed economic prosperity for the nation but also ensure the maximum provision of the welfare of the people.

\section{Scope and justification}

This article relates to public finance in a sociological way, seeking the critical connection between revenue and governance. The report focused on agriculture, which was the mainstay of the Nigerian economy before the discovery of oil in commercial quantity in the late 1950s. Research on agricultural products, such as cocoa with a ready international market and a source of livelihood a population of about 90 million people in the southern part of Nigeria (Ladipo \& Adesinmi, 1975; Idowu, Osuntogun \& Oluwasola, 2007) cannot over-emphasised. To isolate cocoa from other agricultural products, there are about five to six million cocoa farmers in the world with an annual global output of about 4.8 million metric tonnes in 2014 (WCF., 2014; ICCO., 2015). Besides, about 60 and 80 million people derive their means of livelihood from cocoa-related trades (WCF, 2014). Concerning Nigeria, the situation is not disheartening. Research in 2009 carried out by the International Cocoa Organisation and reported at its 2012 meeting in London has shown that while Africa's share of world cocoa output has increased from around $69 \%$ to $72 \%$ at an average annual rate of $3.7 \%$ (ICCO, 2012), Nigeria's contribution has continued to stagnate at about $1.06 \%$ in 2010/2011. From the available figures, Nigeria's production rate fell sharply from about 400 metric tons in the 60 s to about 230 metric tons in 2014 (ICCO, 2015). This study is thus timely, given the need to diversify the economy from oil and the importance of the agricultural sector as a sustainable revenue source and its employment potentials. The comparative advantage that the mostly untapped tropical environment of Nigeria offers in gearing cocoa production as a means of significant cash-crop revenue and a boost in world production is also worthy of consideration. An examination of the political economy of this vital farm product, most notably the determinants of its export, as the output is meant for shipping. Furthermore, Nigeria economy in the last fifty years has witnessed much structural transformation, which culminated in the adoption of various economic measures and policies.

Agricultural export, of which cocoa played a leading role, brought foreign exchange earnings to the government and remained the second-highest foreign exchange-earners after petroleum. There is no doubt that the literature on agricultural export is numerous. However, these studies have significant deficiencies that arise through one or combinations of historical, methodology or conceptual reasons. First, the relative scarcity of data upon which researchers based their studies affected most of the studies. For example, a good number of these studies are based on the impact of SAP on Agriculture, with spans of five to seven years. This period was too short for any meaningful analysis, rendering the conclusions from such studies irrelevant today. Second, some export studies on cocoa neglected other socio-economic and political variables by relying solely on the economic variables, mainly prices. However, some agro-climatic conditions such as rainfall, the quantity of input available in a year, incidences of diseases and pest, age of cocoa plantation and soil condition are equally important in determining the aggregate output of cocoa and hence amount available for export. Besides, the assistance that the farmers could also derive from the government to overcome these challenges hardly found substantial expression in most of the works. Furthermore, there are also studies on the regional analysis of pest control and investment in cocoa production, which differ substantially from the material and method of this research.

However, this research work is also limited to the periods of 1970 to 2019 . The period is considered suitable not only that it offers an extended period for meaningful analysis, but also that it encompasses the economic reengineering and redesigning that have taken place during this period. The period immediately after independence witnessed a lot of political instability, which eventually led to the civil war between 1966 and 1970. Most researchers prefer 1970 as a convenient point to start in that the year signalled the commencement of development plans in Nigeria. Therefore, this study attempts to bridge this gap by considering the current agro-climatic and 
economic variables acting as determinants of aggregate agricultural export. Furthermore, the period of 1970 to 2019, which offers about fifty-year period coupled with the macroeconomic structural changes that have taken place during this period, will provide a more plausible platform upon which meaningful analysis can be based.

\section{The fate of agriculture in Nigeria}

In terms of provisions of employments for arrays of citizens of Nigeria, the position of agriculture as a crucial contributor to the economic development of Nigeria cannot be overemphasised. As Ogbalubi and Wokocha (2013) pointed out, agriculture played a key development role for the country since independence. Paramount among the many roles, as the authors argued, is the provisioning of jobs for about $70 \%$ of the citizenry. As rightly positioned by Izuchukwu (2011) Agriculture has always contributed to the economic development of Nigeria by providing food for the citizens; providing necessary materials for manufacturing; provision of employment; provision of international relations in terms of exporting goods for revenue and establishing trade centres the Agric sector. Before independence in 1960, agriculture has been central to livelihood, which is vital to the development and stability of society.

To further enhance and sustain agricultural development in Nigeria, the government of Nigeria in 1988 enacted the first agricultural policy, which was operated till 2000. By 2001 and subsequently, the national policy on agriculture was reviewed with a focus on the better articulation of the previous policies. As Ademola (2019, p. 1) posited, "the Nigeria Agricultural Policy provides, among others, adequate financing of agriculture". Policies and programmes in Africa, including Nigeria, are intended to eliminate or better still reduced to its barest minimum sufferings and poverty of the populace (Zadawa \& Omran, 2020). The implementation of this national policy on agriculture is further dependent on the macro-economic policies which provide the avenue for the agricultural policy to triumph.

Nigeria's agricultural output continues to suffer setback despite her being the most populous country in Africa with a population of over 160 million people (Kanayo, 2014) and agriculture being the major employer for close to $70 \%$ of the people. Moreover, Nigeria is arguably the second-largest economy in Africa with a GDP of about US $\$ 40$ billion and a considerable array of natural and human resources available, for the most part, in good quality and quantity that should ordinarily make the nation Africa's most attractive economy and political nerve-centre. However, over two-thirds of the population lives below the poverty line of US\$1 per day (Aiyedogbon \& Ohwofasa, 2012; Abdulgafar, Ibrahim \& Alasinrin, 2013; Garga, 2014; Kanayo, 2014). A regular explanation often offered for the relegation of agriculture and the poor economic and political indices is that Nigeria's economy is almost solely dependent on the petroleum sector. Indeed, the oil sector alone accounts for more than threequarters of revenues accruing to the three layers of government and provides approximately $95 \%$ and $80 \%$ of revenue accruing from foreign exchange and of budgetary revenues respectively (Olaiya, 2011). Towing this line of reasoning, the free money being generated from oil proceeds has derailed the governance initiatives in other sectors like manufacturing and agriculture. However, the critical role of agriculture in the economy cannot be overemphasised. Ugwu (2009) argued that the agricultural sector provides $26 \%$ of Nigeria's gross domestic product in $2005,85 \%$ and $10 \%$ of which are generated from crop production and livestock, respectively. Concerning non-oil revenue, Ugwu (2009) further submitted that over 90\% is attributable to agriculture; apart from its employment capacity of about one-third of the total labour force and provision of means of livelihood for the rural populace.

Nigeria is providential with many natural resources, both renewable and non-renewable, in terms of fertile and cultivable land. Before and a few years after independence, these advantages were sizably articulated in terms of domestic subsistence and cash crop productions. Then, the primary source of revenue to the government of both the federal and regional in the late $50 \mathrm{~s}$ and the early $60 \mathrm{~s}$ was predominantly agriculture. The government depended on agricultural export as one of the major sources of government revenue in both domestic and foreign exchange earnings (Ojo, Awe \& Ogunjobi, 2014). Therefore, the main policy thrust of agricultural development then was to encourage agricultural commodity exports to earn the foreign exchange necessary for capital importation from abroad to usher in rapid development. More so, that food supply was never a problem around that period. Up till today, cocoa remains a valuable export commodity in Nigeria, and it is second to petroleum in terms of foreign exchange earnings. It is a source of livelihood to a large number of people in southwestern Nigeria. About $10 \%$ of the aggregate quantity produced in Nigeria is processed locally (Delloitte \& Sells, 1991). Understanding the political economy of cocoa export will go a long way in fashioning policies as regards Cocoa production and marketing.

From 1910, when crop exportation was introduced to what now became known as Nigeria, the Marketing Boards remained the body solely responsible for the export of cash crops like, of which cocoa was dominant. The board operated in this monopoly arrangement until the economic reform of the mid-1980s (Olubanjo, Akinleye \& Ayanda., 2009). From 1986 onward, the liberalisation of the cocoa market by the abolition of the board resulted in improved employment and enhanced market prices to the farmers. The liberalisation also brought the era of prompt payment to farmers and improved output. Therefore, it is pertinent to underscore this review under two broad categories: the studies conducted before deregulation and those after deregulation. The pre-deregulation 
studies emphasised the adverse effect of central pricing through marketing boards and climatic factors as essential determinants of aggregate cocoa output. The empirical study conducted by Olayide and Olatubosun (1974) on the effects of commodity exports on Nigerian economic growth is apt. The study critically analysed the significance of agricultural commodity export to Nigeria's economy by examining the fate of four export commodities, i.e. cocoa, the palm kernel, palm oil and Groundnut under the Commodities Board from 1945 to 1967. They discovered that Nigeria's Gross Domestic Product (GDP) mainly hinged on the commodity export of four principal commodities being managed for exports by the commodity Marketing Board. They argued that farmers in Nigeria were rational and responded positively to high producer prices and therefore argued in favour of an upward review of prices to boost commodity export production.

As Olayide, Ogunfowora and Essang (1974) argued, the adverse effects of the centrally controlled marketing strategy for commodity marketing affected agricultural growth. The conclusions evident from the studies were that the commodity boards pricing policies undermined the growth potential of Nigerian agricultural exports. For Idowu, Osuntogun and Oluwasola (2007) and Adegeye (1986), other factors exist apart from incentives of subsidy and remunerative producer prices affecting cocoa production. They argued that the old age of the cocoa trees, old age of the farmers; smallholdings of the farms; lack or inadequate credit facilities, non-availability, a high cost of necessary input and lack of adequate coordination in the cocoa institutional infrastructure are additional factors drawing back the hands of the clock. They argued that the aggregate output of cocoa had been on the decline due to various price disincentives in place. As Oshikanlu (1982) argued, that progressive lack of renewal strategy for replacing old trees that have outspent their expected economic life contributed immensely to the declining production of cocoa. In Oni (1971), the shortcomings associated with the tacit utilisation of the Marketing Board as a form of taxation on the farmers were brought to the fore. By paying farmers a price that fell short of the world price of cocoa, Oni (1971) argued that producers of cocoa were discouraged from increasing productions, as such will not possibly increase returns. Consequently, these studies are eloquent descriptive critiques of the reasons for the decline in the cocoa export before the liberalisation era that commenced in the mid-1980s.

\section{Challenges to Nigerian agricultural policies}

Agriculture contributes significantly to the economic development of Nigeria. Agriculture has been one of the key players to the development of the country since independence providing jobs for about $70 \%$ of its citizenry (Ogbalubi \& Wokocha, 2013). As rightly positioned by Izuchukwu (2011), agriculture has always contributed to the economic development of Nigeria by providing food for the citizens; providing necessary materials for manufacturing; provision of employment; provision of international relations in terms of exporting goods for revenue and establishing trade centres the Agric sector. Before independence in 1960, agriculture has been central to livelihood, which is vital to the development and stability of society.

To further enhance and sustain agricultural development in Nigeria, the government of Nigeria in 1988 enacted the first agricultural policy, which was operated till 2000. By 2001 and subsequently, the national policy on agriculture was reviewed with a focus on the better articulation of the previous policies. "The Nigeria Agricultural Policy provides, among others, adequate financing of agriculture" (Ademola, 2019). Policies and programmes in Africa, including Nigeria, are intended to eliminate or better still reduced to its barest minimum sufferings and poverty of the populace (Zadawa \& Omran, 2020). The implementation of this national policy on agriculture is further dependent on the macro-economic policies which provide the avenue for the agricultural policy to triumph.

Right from independence in 1960, agriculture has been one of the contributors to the economic development in Nigeria, contributing to more than 50\% of its Gross Domestic Product (GDP) (Izuchukwu, 2011). Agricultural production and development have been the base for expanding the growth and reducing poverty of the developing economies (Sertoglu, Ugural, \& Bekun, 2017). Agriculture is the dominating sector of the Nigerian economy and has accounted to be the majority source of living to the population (Ademola, 2019). The economy of Nigeria in the pre- and post-independent decades survives on the dependence on the agricultural sector. Over the years, the role of agriculture on the Nigerian economy adversely changed tremendously. A group of scholars have, however, argued that the agricultural sector is the panacea for winning or losing the battle in any society where the war for economic development persists (Sertoglu, Ugural, \& Bekun, 2017). Sertoglu, Ugural, and Bekun, (2017) discovered that agricultural production and GDP in Nigeria have a long-lasting equilibrium relationship, they, therefore, asserted that agricultural productivity has a positive contribution to economic development in Nigeria. They recommended, among others that governmental policies and allocation should be more enhanced in the agricultural sector of Nigeria.

Just as contributed by Biam, Okorie and Nwibo (2016) in their study, they recommended that governmental policies aim at increasing farmer's productivity on the economy should be targeted, educational level of the farmers should also be improved, and farmers should afford their access to fertiliser and credit. These they believe will enhance the development of the agrarian sector on the economy. Muhammad-Lawal and Atte (2016) conducted a study focusing on growing the Nigerian economy through agriculture. They discovered that GDP, population and 
consumer price index are factors affecting agricultural productivity. The authors, therefore, recommended that agricultural productivity through improved mechanised technology would boost the nations per-capita income. The situation calls for urgent action by re is an urgency for the government to diversify the economy into agricultural production to boost the growth of the economy (Adams, 2016). The Agricultural sector of Nigeria has been considered important in establishing the nation's economic growth (Enilolobo, Mustapha, \& Ikechukwu, 2019). Over the past few decades, unemployment contributed to the significant challenges confronting the Nigeria economic sector, as unemployment rises due to the number of graduates produced by the Nigeria tertiary institutions. With the extensive nature of the agricultural sector, young youths are absorbed to enhance the development of the economy of Nigeria through agricultural development. Thus, unemployment in Nigeria is alleviated through the contributions of the agricultural sector.

According to Olanrewaju (2014), there is a relationship between youth involvement in agriculture and unemployment in Nigeria. Olanrewaju (2004) revealed that Nigerian youth in the absence of white-collar jobs are ready to engage in agricultural practices once there is a provision of enabling environment from the government through funding of the agricultural sector. This is because agricultural development plays a significant role in promoting youth participation, thereby reducing joblessness in society. Enilolobo and Ohalete (2017) revealed that reduction in unemployment and poverty is as a result of agricultural output, thereby noting that agriculture has become a veritable tool to economic growth and development. The study suggested that the government, research institutions and private individuals in developing agriculture in Nigeria should pay serious attention.

The government of Nigeria has enunciated policies to help foster the growth of the agricultural sector. In 2015, the government tightened up its policy on foreign exchange to improve local production by banning some products from importation into the country (Opebiyi, 2020). This policy aimed at improving the economy through the encouragement of local production. Products banned from importation by the Nigerian Customs Service, for example, will encourage the consumption of fresh and healthy products (Nigeria Custom Services, 2018). This policy, though, has failed to improve the living of the majority; this is because the items produced locally are not that cheap and affordable by the generality of the people (Opebiyi, 2020). Nigerians were advised not to consume foreign rice because of importation and tendency of selling at exorbitant prices (National Agency of Nigeria, 2018).

The Nigerian government made a move in providing credit facilities to farmers and those engaged in agricultural production, which enables them access to loans. The major challenge faced by the farmers in Nigeria is that more than $70 \%$ of the farmers are said to be predominantly poor and uneducated and as thus can not meet the requirements for the qualification to these loans (Zakaree, 2014). Because more than 90\% of rural dwellings farmers are involved in subsistence farming, the federal government established the Agricultural Credit Guarantee Scheme fund (ACGSF) to serve as an assurance for access to loans to help boost their productivity (Zakaree, 2014). The disbursement and management of this fund are under the care of the Central Bank of Nigeria. The focus is to reduce to the barest minimal the delay and bottlenecks that could be encountered in getting access to the credit facilities by the farmers.

The credit scheme intervention by the central bank is targeted at those into the agricultural business, including producing, processing, and storing of agricultural produces for commercial purposes. The objectives of the scheme are to

1. foster the developing of the Nigerian agrarian sector through the provision of loan facilities to farmers who engage in extensive scale commercial activities;

2. enhance national food security through increased food supply;

3. reduce loan charges of farmers engaged in agricultural production to enable them to explore possibilities in the sector; and

4. increase productivity, thereby generating employment and also diversifying the nation's income base.

Over the years, the government has provided an avenue to enhance the sustainability of food and agriculture. By way of budgetary interventions, provisions of funding facilities were made to the farmers with low capacity and those in the agrarian sector by the commercial banks (Opebiyi, 2020). The government then prioritised sustaining agricultural produces, for the benefit of protecting and improving local produce and agriculture business (Ajani \& Igbokwe, 2014). The programme aimed at improving the supply of seed and fertiliser to farmers. The Green Alternative is an aftermath of the Agricultural Transformation Agenda, was propagated under the Agricultural Promotion Policy 2016-2020 (FMARD, 2018). This intervention focused on enterprises development in the agrarian business. Also, the programme is arguably to sustain and stimulate agricultural production and stabilise prices. This initiative also focuses on supporting the farm business through the sustenance of natural resources, thereby generating enhanced production and personnel in the agrarian sector (FMARD, 2018). Another aim of the programme is to expose the general public to the agricultural industry.

The achievement of the programme is slim. Consequently, the policy is yet to record a meaningful change in ensuring that supply meets the quantum of demand. Also, there has been an increase in prices of food items compare to what it was before the intervention. Also, despite this intervention, items are still being smuggled into the country. 
The main thrusts of the Agricultural Promotion Policy are to

1. boost the enlightenment of the general populace through advertising the benefits of climate-smart agriculture;

2. strengthen of institutional and partnership linkages for proper governing and legislating of climate-smart agriculture;

3. assess the environmental impact before carrying out major agricultural projects;

4. ensure the involvement of the private sector in the promotion of renewable energy;

5. create of wide-ranging public and stakeholder alertness on Climate-Smart Agriculture;

6. facilitate of soil map for managing and improving land usage; and

7. expansion of conventional acceptable modalities or procedures on the of climate change;

The following, according to Nwankpa (2017) and Matemilola and Elegbede (2017), are the significant challenges confronting the agricultural development in Nigeria.

- The setback to the focus on agriculture created by the discovery of crude oil in commercial quantity at Oloibiri in the present-day Rivers State in the late 1950s and the resultant monocultural oil economy from the 1970s.

- Absence of youthful energy in agricultural production due to the influx of otherwise young farmers from rural to urban areas in response to the pull factor of crude oil production.

- The dysfunctional transportation system that hampers farmers from linking farmer with the urban markets in good time.

- The dearth of credit facilities for smallholder farmers to expand beyond subsistence farming and local market patronage.

- Corrupt practices in the governmental intervention schemes, which leads to the diversion of subsidised farming chemicals and equipment from reaching the targeted farmers.

- Overdependence on traditional and cultural farming practices in an era of global best practices in mechanised farming.

- Governance crisis impacting on a focussed and policy-driven agricultural sector.

- The crisis of overpopulation that limits per-capita land allocation and exerts pressure on farmers to embark on the farming of immediate gains.

- Gender discrimination against women's participation and the accompanied limitation on total output.

- Poor conflict management among farmers that creates an artificial gap in output.

- Ecological and environmental degradation.

\section{The effect of crude oil exploration on agriculture in Nigeria}

Nigeria's economy is monolithic and heavily reliant on proceeds from oil revenue, which like every other issue in the country, the political terrain and the economic crises that determine the volume of cocoa production revolves around petroleum. If at all there are pockets of attempts, successive governments have not been quite successful in diversifying the economy away from the perenial monocultural oil sector. A pedestal measure would have been to consider the alternative provided by Nigeria's favourable climatic conditions suitable for various agricultural products. Hence, for lack of a sound macroeconomic framework of diversification, the unstable politics, corrupt practices, un- and under-developed inadequate infrastructure, and a host of other adverse manifestations have hobbled oil-rich Nigeria. Bandura and Hammond (2018) gave a critical account of how the torrential revenue from crude oil eclipsed the booming agricultural potentials of Nigeria. Needless to stress that such crises of governance are frequent in oil-dependent states, especially in the developing economies (Olaiya, 2014). As Diamond (2008) submitted, "not even a single one" of the 21 countries whose economies are dominated by revenue from oil "is a democracy". According to him, oil states are deficient in the "connective tissues" that induce political accountability. Olomola and Adejumo (2006) and Adegeye (1990) demonstrated how 'oil price shock' affected Nigeria's economic governance by adversely impacting on other macroeconomic activities. Eifert, Gelb and Talttrot (2003) argued that, except for Norway, real per-capita income in oil-dependent countries had declined continuously by as high as $18 \%$, and the poverty prevalence is consistently on the increase in most resourcedependent states. For Coolidge and Rose-Ackerman (1997), oil revenue encourages rent-seeking behaviour. It produces at best the "benevolent autocrat" regimes (like in Saudi Arabia, Libya, Kuwait and Venezuela) and at worst "pure kleptocrat" regimes (Nigeria, Angola, Sudan and Iraq), with dictatorial regimes (Iran, Libya, Chad and Syria) claiming the monopoly of governance direction in the chink.

Throughout the 1960s and early 1970s, the cocoa industry was a significant factor in Nigeria's economic development. In particular, cocoa exports in the first part of the 1970 s accounted for $45 \%$ foreign exchange revenue (Nkang, Agom, Abang \& Orok., 2007). Then, the aggregate cocoa production stood at virtually 400,000 tones. However by 2013, cocoa export dropped drastically to less than 200,000 tonnes and, due to the continued emphasis on exploration and exploitation of crude oil, cocoa and other agricultural product accounted, according to 
Wikipedia online Encyclopedia, for less than $2 \%$ of Nigeria's total foreign earnings. To be specific, cocoa exports account for less than $2 \%$ of the full export earning in Nigeria (Adebiyi \& Okunlola, 2013; Adefila, 2013). From table 1 , it is evident that the 1970s witnessed a significant decline in the non-oil sector in Nigeria. The agricultural sector faced the most significant challenge by dropping to less than 50\% contribution to GDP from about $70 \%$ in the preceding decades and later to as low as $16.05 \%$ in 2005 (Olaiya, 2016).

Table 1: Yearly sectorial contribution to GDP in Nigeria as available, 1960-2005

\begin{tabular}{|l|l|l|l|l|l|l|l|l|l|}
\hline Sector/Year & 1960 & 1970 & 1980 & 1990 & 2000 & 2002 & 2003 & 2004 & 2005 \\
\hline Agriculture & 69.90 & 47.94 & 26.91 & 26.34 & 20.65 & 20.52 & 16.21 & 16.21 & 16.05 \\
\hline Crude oil & 1.13 & 11.27 & 20.25 & 26.91 & 47.53 & 34.58 & 41.50 & 37.22 & 49.64 \\
\hline Manufacturing & 4.80 & 7.20 & 9.18 & 4.46 & 3.44 & 6.51 & 4.70 & 3.06 & 3.62 \\
\hline Others & 24.17 & 33.59 & 43.66 & 42.29 & 28.38 & 22.39 & 21.20 & 25.51 & 4.91 \\
\hline Total GDP & 100 & 100 & 100 & 100 & 100 & 100 & 100 & 100 & 100 \\
\hline
\end{tabular}

Source: Ogwumike \& Ogunleye, 2008.

The situation has led to near-total neglect of other sectors such as the agricultural sector and especially cocoa sub-sector production. Still, cocoa remains relevant despite the years of neglect. According to Foraminifera (2015), a market research organisation based in the Lagos State of Nigeria, cocoa remains key non-oil revenue earnings from foreign exchange for Nigeria. The organisation argued that cocoa is planted in fourteen (14) of the Nigerian 36 federating states, namely Ondo, Cross River, Oyo, Osun, Ekiti, Ogun, Edo, Kogi, Akwa Ibom, Delta, Abia, Kwara, Ebonyi and Rivers. The relevance is nevertheless facing various challenges ranging from average trees, elderly farmers, government inattention, among other things.

It is pertinent to stress that, despite the availability of about 700,000 hectares of land arable and available for cocoa production and lying fallow (Adebiyi and Okunlola, 2013), no proper policy has been enunciated by the government on cocoa. Due to this, farmers and their farms have continued to deteriorate in production capacity. Moreover, the lack of coordinated effort from the government has led to individual small farms with average plantation of more or less $2-4$ hectares. Moreover, due to the weak quality control mechanism, the poor farmers have had to make use of crude implements rather than mechanised farming. The inevitable lack of know-how and its attendant diseases and pest attacks have led ultimately to low yields, both in quantity and quality. The situation perhaps explains why Nigeria lags far behind countries like Cote d'Ivoire with a population of about 29 million people producing over 1,300,000 metric tonnes yearly; and Ghana with a population of about 20 million producing over 950,000 metric tonnes annually (Kulepa, 2013).

\section{Liberalisation efforts and the challenges}

The government embarked on several attempts to liberalise the Nigerian economy. For this article, the Structural Adjustment Programme (SAP) generally considered to be the most notorious of the attempts and, perhaps, the most relevant to rent-seeking nature of the Nigeria economy is focussed. In 1986, the military regime in Nigeria, led by General Ibrahim Badamosi Babangida, introduced a trade liberalisation, tagged "Structural Adjustment Programme (SAP)", put together by the World Bank and the International Monetary Fund (IMF). The essence of the programme was to tackle the twin problem of declining oil prices at the world market and the pervasive institutional inefficiency. Virtually, the government abolished the agricultural institutions such as marketing board; privatised many public enterprises; devalued the currency; and liberalised exportation of cash crops. With these, the local-price of agricultural products such as cocoa, among other cash crops, received a boost. In effect, the market liberalisation dominated studies on some specific agricultural production following the adoption of deregulation policy in 1986 and dissolution of the marketing boards. At that time, agricultural pricing policies became subjected to the price mechanism, which thus culminated in studies that weighed the effects of deregulation policies on cocoa production, marketing and exports.

Scholarly works have generally been ambivalent in their results on the impacts of SAP on agricultural output in Nigeria. The focus of the study by Adegeye and Dittoh (1988) was the price effect of the adoption of the Structural Adjustment Programme (SAP) on cocoa. They argued that even though the SAP induced a boom in cocoa output and export in Nigeria, the situation could be short-lived because the explosion could induce massive production, which they argue could harm the price. Ajobo (1989) empirical study focused on examining the link (if any) between the Nigerian market and the international market following the adoption of SAP. Using the simulation quantitative model technique, he observed that the inception of SAP witnessed a significant direct linkage of the Nigerian cocoa market to the world market. In the same vein, Delloitte and Sells (1990) examined the economic issues and the effect, which the liberalisation arrangement of cocoa is capable of exerting. He argued that the effect could be both positive and adverse. He submitted that the new policy could lead to increased income to the producers; increased income to the government to provide necessary facilities due to the reduction or complete elimination of the subsidy element that used to pose a severe financial drain on government resources, and the increased foreign exchange earnings as more cocoa were being exported. However, he pointed out that the rush to produce and export more may lead to the exportation of low-grade cocoa which in the long run may demean 
the integrity of Nigerian product in the comity of cocoa producers.

Idowu, Osuntogun and Oluwasola. (2007) argued that the production of cocoa in Nigeria still lied with smallholding farmers despite the introduction of liberalisation about twenty years ago. They submitted that, beyond any open-market policy, the combined determinant of substantial "aggregate cocoa output" is "sustained increase in real producer prices, local currency devaluation and increased supply of chemical fertilisers". For Arene and Nwachukwu (2013), trade policy on liberalisation must be accompanied with the assistance of farmers on climatic conditions to put the fluctuating cocoa output in the desired direction. Usman (2000) and Nwachukwu, Agwu, Nwaru \& Imonikhe. (2010) examined the readiness of Nigeria to compete favourably in the world market in terms of non-oil exportability and elements. They argued that notwithstanding the fact the tropical forest region in which Nigeria is situated should confer on her the comparative advantage, cash crop exports have only improved marginally.

Furthermore, the study conducted by Folawewo and Olakojo (2010) on the export capacity of Nigeria to the world volume of trade was examined. They argued that global factors are the primary determinant of Nigeria's capacity in agricultural export. While the past output constitutes the endogenous factor, the world price of Nigeria's agricultural products and the income generated from its trades in the world market are the exogenous determinants. Ajetomobi (2011), in a study titled "Market Power in Nigerian Domestic Cocoa Supply Chains", argued that though the Cocoa Marketing Board was scrapped to pave the way for the overall market and pricing efficiency of cocoa production to improve farmers income, the terrains have been mainly taken over by exporting firms who are also acting in like manner of cartel and trust. The argued that such anti-competitive behaviour might not augur well for the policy target. For Adeyeye (2001), the liberalisation only created a monopsony situation in which large cocoa processing companies like Nestle and Cadbury took the place of the marketing board. The situation, rather than improve yields, attuned the minds of the farmers to price values of their product.

Using the constructs of export performance and finance, Onaolapo and Odeyemi (2011) critically assessed the link between export financing and the capacity of the intermediary cocoa processing companies in the southwestern region of Nigeria. The authors found a critical result that could assist policymakers on the effectiveness of cocoa intervention funds. They argued that whereas loans accessed from commercial banks and profits injected impacts significantly on Nigeria's ability in cocoa exports, resources from development banks were not so significant. Also, the examination of the "effects of incentives granted by the Federal Government to encourage cocoa exports on the productivity and efficiency of cocoa export processing factories" by Akinfolarin, Oseni and Imoudu. (2012, p. 1) revealed vital information that could assist agriculture and reduce overreliance on oil revenue in Nigeria. The research revealed that production expenses for cocoa are highly expensive for most of the companies. Invariably, most of the companies operate at a loss. Conversely, the study conducted by $\mathrm{Yu}$ and Nin-Pratt (2011) showed the performance of agriculture in Sub-Saharan Africa recorded a noteworthy improvement between the mid-1980s and late 2000 after decades of declining performance. The reasons, they argued, are robustly connected to the more proficient production technique adopted over the period.

In all, the literature has shown that agricultural exports experienced various challenges from government, farmers and climatic conditions. However, a yawning gap begging for attention is identifying holistic exogenous variables that determine the aggregate agricultural output and export. These variables, in addition to the ones already studied and reviewed, include climatic conditions, disease control and policy intervention, and government assistance in all of these.

\section{Conclusion}

This review article made a modest attempt to link the near-exclusive reliance of Nigeria's public finance on oil revenue to the neglect of agriculture, which was a booming source of income for colonial Nigeria before the discovery of oil at Oloibiri, in Niger Delta Region in 1956. The article adopted a sociological approach, fiscal sociology developed by the duo of Goldscheid and Schumpeter, to critically drew a nexus between the current lifethreatening revenue profile of Nigeria and her major, if not sole, reliance on petrodollar as well as the socio-cultural manifestations. For empirical connection to the research objectives, examples were drawn from cocoa production as a representation of the agriculture sector of the economy. Extant literature was reviewed in line with significant areas of the stated objectives, such as fiscal sociology, agricultural crisis and other ancillary spaces.

Various studies examined in the article revealed that the successive government of Nigeria treated the torrential oil proceeds for granted and made no meaningful effort to liberalise the economy. In the process, public financial management has been epileptic and inadequate due to the volatility in global oil prices. The three tiers of government, therefore, faced a financial crisis leading to their inability to provide basic amenities for the citizens in their various legislative assignments. Hence, the article keyed into the sociological discourse of the finances, particularly in regards to the dwindling agricultural status, and the multiple socio-economic, political and cultural distortions embedded in its monolithic source of revenue. The literature is replete with the sociological analysis of pubic financial management. Critical analysis of the article reveals, however, showed a disproportionate concentration on public economies of the advanced democracies. This article focused on the deleterious interplays 
between the dominant oil income and agricultural outputs and how the duo has made Nigeria a rentier economy. A well-Integrated set of literature on the sociology of oil politics; the institutional and symbolic element of the tax-dependent economy; and the historical volatility of rentier economies were reviewed. In all, the essay advanced the significance of fiscal sociology as a veritable tool for constructing a theory about Nigeria's volatile public finance.

\section{References}

Abdulgafar, D. S., Ibrahim, W., \& Alasinrin, K. A. (2013). The extent of achieving the millennium development goals: Evidence from Nigeria. Kuwait Chapter Arabian Journal of Business Management Review, 2, 59-71.

Abiola, A. G., \& Okafor, H.O. (2013). Searching for appropriate crude oil price benchmarking method in the Nigerian budgeting process. Developing Country Studies, 3(12), 57-71.

Adams, O. K. (2016). Diversification of Nigeria economy through agricultural production. Journal of Economics and Finance, 7(6), 104-107.

Adebiyi, S., \& Okunlola, J. O. (2013). Factors affecting adoption of cocoa farm rehabilitation techniques in Oyo State of Nigeria. World Journal of Agricultural Science, 9, 258-265.

Adefila, J. O. (2013). Spatial effects of cocoa production on rural economy in Idanre-Ifedore Area, Ondo State of Nigeria. Asian Journal of Agriculture and Rural Development, 3, 56-66.

Adegeye, A. J. (1986). Price Incentives for Major Agricultural Export Crops in Nigeria: The case of cocoa. In A. J. Adegeye \& W. O. Ajayi (Eds.), Cocoa revolution in Nigeria (pp. 139-148). University of Ibadan Press, Ibadan, Nigeria.

Adegeye, A. J. (1990). A comparative analysis of the costs of production and producer prices of a tonne of cocoa from matured trees in Nigeria before and during the Structural Adjustment Programme (SAP). Ife Journal of Agriculture, 12, 120-129.

Adegeye, A. J., \& Dittoh, S. (1988). Is there a structurally adjusted induced boom in the Nigerian cocoa industry? Proceedings of the Nigerian Economic Society Conference, May 3-5, 1988, Obafemi Awolowo University, Nigeria.

Ademola, A. E. (2019). Impact of Agricultural Financing on Nigeria Economy. Asian Journal of Agricultural Extension, Economics \& Sociology, 31(2), 1-13.

Adeyeye, C. T. (2001). Cocoa production and price stability: An industrial relations perspective. An ILO Research Paper. International Labour Organization (ILO), Geneva, Switzerland.

Aiyedogbon, J. O., \& Ohwofasa, B. O. (2012). Poverty and youth unemployment in Nigeria, 1987-2011. International Journal of Business and Social Sciences, 3, 269-279.

Ajani, E. N., \& Igbokwe, E. M. (2014). A review of agricultural transformation agenda in Nigeria: The case of public and private sector participation. Research Journal of Agriculture and Environmental Management, $3(5), 238-245$.

Ajetomobi, J. O. (2011). Market power in Nigerian domestic cocoa supply chains. Proceedings of the CSAE Conferences and Workshops: 2011 Annual Conference, March 20-22, 2011, Antalya, Turkey.

Ajobo, O. A. (1989). A simulation model of Nigeria's economy under free-market systems. Ph.D. Thesis, Department of Agricultural Economics, Obafemi Awolowo University, Ife, Nigeria.

Akhaine, S. O. (2010). Nigeria: Politics and the end of oil. Review of African Political Economy, 37(123), 89-91.

Akinfolarin, A. O., Oseni, J. O., \& Imoudu, P. B. (2012). Operational activities of cocoa export processing factories in Ondo State, Nigeria. Journal of Agricultural Science, 3, 1-13.

Andic, F. M., \& Andic, S. (1985). An exploration into fiscal sociology: Ibn Khaldun, Schumpeter, and public choice. FinanzArchiv/Public Finance Analysis, New Series, 43(3), 454-469.

Arene, C. J., \& Nwachukwu, E. C. (2013). Response of cocoa export market to climate and trade policy changes in Nigeria. Journal of Agriculture \& Sustainability, 4(2), 245-277.

Atria, J., Biehl, A., \& Labarca, J. T. (2019). Towards a fiscal sociology of Latin America. European Review of Latin American and Caribbean Studies, 107, 139-150.

Bandura, R., \& Hammond, M. (2018). Introduction: Nigeria case study. In R. Bandura \& M. Hammond (Eds.) The future of global stability: The world of work in developing countries (pp. 1-3). Center for Strategic and International Studies (CSIS).

Bernard, O. A., \& Adenuga, O. (2017). Agricultural sector development as a panacea for employment generation in Nigeria. International Journal of Economics, Business and Management Research, 1(2), 251-257.

Biam, C. K., Okorie, A., \& Nwibo, S. U. (2016). Economic efficiency of small scale soyabean farmers in Central Agricultural Zone, Nigeria: A Cobb-Douglas stochastic frontier cost function approach. Journal of Development and Agricultural Economics, 8(3), 52-58.

Campbell, J. L. (1993). The state and fiscal sociology. Annual Review of Sociology, 19, 163-185.

Campbell, J. L. (2009). Epilogue: a renaissance for fiscal sociology? In I. W. Martin, A. K. Mehrotra \& M. Prasad (Eds.) The new fiscal sociology: Taxation in comparative and historical perspective (pp. 256-266). 
Cambridge University Press.

Central Bank of Nigeria (CBN). (2018). Agricultural credit guarantee scheme fund (ACGSF). Retrieved from: www.cbn.gov.ng/Devfin/acgsf.asp. Accessed 2nd January 2020

Central Bank of Nigeria (CBN). (2020a). Crude Oil Price (US\$/Barrel), Production (mbd) and Export (mbd). Accessed 24/04/2020 from https://www.cbn.gov.ng/rates/crudeoil.asp?year=2019

Central Bank of Nigeria (CBN). (2020b). Daily crude oil price. Accessed 24/04/2020 from https://www.cbn.gov.ng/rates/DailyCrude.asp

Coolidge, J., \& Rose-Ackerman, S. (1997). High-level rent-seeking and corruption in African regimes: Theory and cases. Policy Research Working Paper WPS 1780, The World Bank. http://siteresources.worldbank.org/INTWBIGOVANTCOR/Resources/wps1780.pdf.

Delloitte, H., \& Sells, A.(1990). Cocoa marketing in Nigeria. Economic Development Institute of the World Bank (EDI) Working Papers of Agriculture and Rural Development.

Diamond, L. (2008). The spirit of democracy: The struggle to build free societies throughout the world. Henry Holt and Company, New York.

Eifert, B., Gelb, A., \& Talttroth, N. B. (2003). Managing oil wealth: The political economy of oil-exporting countries. Finance and Development, 40, 33-60.

Enilolobo, O. S., \& Ohalete, E. E. (2017). Impact of inclusive growth determinants on agricultural output in Nigeria. African Journal of Sustainable Development, 7(2), 141-157.

Enilolobo, O. S., Mustapha, S. A., \& Ikechukwu, O. P. (2019). Nexus between Agriculture and Unemployment in Nigeria. Journal of Economics, Management and Trade, 1-13.

Federal Ministry of Agriculture and Rural Development (FMARD). (2018). The Green Alternative. Retrieved from: https://fmard.gov.ng/the-green-alternative. Accessed 2nd January 2020

Federal Ministry of Agriculture and Rural Development (FMARD). (2016). The Agriculture Promotion Policy (2016-2020) Building on The Successes of the ATA, Closing Key Gaps. Policy and Strategy Document, 2016. Retrieved from: https://fscluster.org/sites/default/files/documents/2016-nigeria-agricsector-policyroadmap_june-15-2016_finall.pdf. Accessed 2nd January 2020

Federal Ministry of Budget and Planning (FMBP), (2016). The Nigerian Budget. FMBP.

Folawewo, A. O., \& Olakojo, S. A. (2010). Determinants of agricultural exports in the oil-exporting economy: Empirical evidence from Nigeria. Journal of Economic Theory, 4, 84-92.

Foraminifera (2015). Raw cocoa seed processing and export in Nigeria: The feasibility report. Foraminifera Market Research, Lagos, Nigeria, January 2015.

Garga, E. (2014). State of the economy: Poverty reduction efforts: Conceptual, theoretical issues, challenges and problems. Research Journal, Organizational Psychology and Educational Studies, 3, 40-45.

Genova, A., \& Falola, T. (2003). Oil in Nigeria: A bibliographical reconnaissance. History in Africa, 30, 133-156.

Gordon, D. B. (2011). Nigeria's economy. In C. J. Kinnan, D. B. Gordon, M. D. DeLong, D. W. Jaquish \& R. S. McAllum (Eds.), Failed State 2030 Report Subtitle: Nigeria-A Case Study (pp. 39-53). Air University Press.

ICCO (2012). The world cocoa economy: Past and present. Report of One hundred and Forty-Sixth Executive Committee, International Cocoa Organisation (ICCO), London, UK., September 18-21, 2012.

ICCO (2015). Production of cocoa beans. ICCO Quarterly Bulletin of Cocoa Statistics, XLI(1), Cocoa Year 2014/15, International Cocoa Organisation (ICCO), London, UK.

Idowu, E. O., Osuntogun D. A., \& Oluwasola, O. (2007). Effects of market deregulation on cocoa (Theobroma cacao) production in Southwest Nigeria. African Journal of Agricultural Research, 2, 429-434.

Izuchukwu, O. (2011). Analysis of the contribution of agricultural sector on the Nigerian economic development. World review of business research, 1(1), 191-200.

Jhingan, M. L., 2008. Advanced Economic Theory (Micro and Macro Economics). 12th Edn., Vrinda Publications Ltd., Mumbai, India.

Kanayo, O. (2014). Poverty incidence and reduction strategies in Nigeria: Challenges of meeting 2015 MDG targets. Journal of Economics, 5, 201-217.

Kulepa, A. (2013). An analysis of the determinants of cocoa exports in Nigeria (1970-2010). MBA Thesis, Obafemi Awolowo University, Ile-Ife, Nigeria.

Kumar, A. (2005). Nigeria: Political economy of oil. Economic and Political Weekly, 40(24), 2454-2455.

Ladipo, O., \& Adesinmi, A. (1975). Cocoa industry in Nigeria: Some aspects of production and consumption. Proceedings of the 5th International Cocoa Research Conference, September 1975, Ibadan, Nigeria, pp: 521529.

Mahler, A. (2010). Nigeria: A prime example of the resource curse? Revisiting the oil-violence link in the Niger Delta. German Institute for Global and Area Studies (GIGA)

Martin, I. W., \& Prasad, M. (2014). Taxes and fiscal sociology Author. Annual Review of Sociology, 40, 331-345

Matemilola, S., \& Elegbede, I. (2017). The challenges of food security in Nigeria. Open Access Library Journal, 4(12), 1-22. 
Moller, J. (2007). Wherefore the liberal state?: Post-Soviet democratic blues and lessons from fiscal sociology. East European Politics and Societies: and Culture, 21(2), 294-315.

Muhammad-Lawal, A., \& Atte, O. A. (2016). An analysis of agricultural production in Nigeria. African Journal of General Agriculture, 2(1), 1-6.

Mumford, A. (2008). Towards a fiscal sociology of tax credits and the fathers' rights movement. Social \& Legal Studies, 17(2), 217-235.

Nigeria Custom Services. (2018). Import Prohibition List. Retrieved from: www.customs.gov.ng/ProhibitionList/ import.php. Accessed 2nd January 2020

Nkang, M., Agom, A. J. A. H., Abang, O., \& Orok, E. D. E. T. (2007). Investment in cocoa production in Nigeria: A cost and return analysis of three cocoa production management systems in the Cross River State cocoa belt. Journal of Central European Agriculture, 8, 81-90.

Nwachukwu, I. N., Agwu, H., Nwaru, J. C., \& Imonikhe, G. (2010). Competitiveness and determinants of cocoa export from Nigeria. Report and Opinion, 2, 51-54.

Nwajiaku-Dahou, K. (2012). The political economy of oil and 'rebellion' in Nigeria's Niger Delta. Review of African Political Economy, 39(132), Special issue: Markets and identities in Africa: honouring Gavin Williams, 295-313.

Nwankpa, N. (2017). Sustainable agricultural development in Nigeria: a way out of hunger and poverty. European Journal of Sustainable Development, 6(4), 175-184.

Nwasomba, C., \& Alumona, V. (2013). Militancy in the Niger Delta and the deepening crisis of the oil economy in Nigeria. Africa Development, 38(3-4), 21-32.

Ogbalubi, L. N., \& Wokocha, C. C. (2013). Agricultural development and employment generation: The Nigeria experience. OSR Journal of Agriculture and Veterinary Science (IOSR-JAVS) e-ISSN, 2319-2380.

Ogwumike, F. O., \& Ogunleye, E. K. (2008). Resource-led development: An illustrative example from Nigeria. African Development Review, 20(2), 200-220.

Ojo, E. J., Awe, I. T., \& Ogunjobi, J. O. (2014). Agricultural export and economic growth in Nigeria: A multivariate Johansen cointegration analysis. Int. J. Arts Commerce, 3, 89-98.

Olaiya, T. A. (2011). Tax administration and burden of governance in Nigeria and Ghana: A comparative analysis. Lap Lambert Academic Publishing

Olaiya, T. A. (2014). Youth and ethnic movements and their impacts on party politics in ECOWAS member states. Sage Open. 10.1177/2158244014522072

Olaiya, T. A. (2016). Examining the political-economy of cocoa exports in Nigeria. International Journal of Applied Economics and Finance. 10(1-3), 1-13.

Olanrewaju, T. J. (2014). Driving youth participation in agriculture through agricultural sector development and funding: Panacea to unemployment in Nigeria. International Journal of Economics, Commerce and Management, 11(5), 6-13.

Olayide, S. O. \& Olatubosun, D. (1974). Effects of Nigerian commodity marketing boards on the output and income of primary producers. In T. O. Adekanye (Ed.), Readings in Agricultural Marketing (pp. 75-91). Longman.

Olayide, S. O., Ogunfowora O., \& Essang, S. M. (1974). Effects of marketing board pricing policies on the Nigerian economy: A systems simulation experiment. Journal of Agricultural Economics, 25, 289-309.

Olomola, P. A., \& Adejumo, A. V. (2006). Oil price shock and macroeconomic activities in Nigeria. International Research Journal of Finance and Economics, 3, 28-34.

Olubanjo, O. O., Akinleye S. O., \& Ayanda, T. T. (2009). Economic deregulation and supply response of cocoa farmers in Nigeria. Journal of Social Sciences, 21, 129-135.

Onaolapo, A. R., \& Odeyemi, J. T. (2011). Relationship between export finance and cocoa export performance in intermediate cocoa processing firms in Southwestern zone of Nigeria. International Journal of Economic Development Research and Investment, 2, 112-121.

Oni, S. A. (1971). An economic analysis of provisional and aggregate supply response among Nigerian cocoa farmers. Ph.D. Thesis, University of Ibadan, Nigeria.

Opebiyi, F. M. (2020). Public Policy on Sustainable Food and Agricultural Markets: Legal Perspective from Nigeria. International Business, Trade and Institutional Sustainability (pp. 349-367). Springer, Cham.

Oshikanlu, J. A. (1982). Economics of cocoa production in Oranmiyan local government area of Oyo State. M.Sc. Thesis, Department of Agricultural Economics, University of Ife, Nigeria.

Oyibo, O., Zakari, A., \& Rekwot, G. Z. (2013). Agricultural budgetary allocation and economic growth in Nigeria: Implications for agricultural transformation in Nigeria. Consilience, 10, pp. 16-27.

Sayne, A., \& Hruby, A. (2016). Nigeria's oil revenue crunch falling prices and increased competition strain the economy and stability. Atlantic Council

Sertoglu, K., Ugural, S., \& Bekun, F. V. (2017). The contribution of agricultural sector on economic growth of Nigeria. International Journal of Economics and Financial Issues, 7(1), 547-552. 
Spinoza, J., \& Vallee, O. (2008). After the Oil: Sketch of a Shipwreck foretold? In Nigeria: Is the end of Mafia politics in sight? Egmont Institute.

Ugwu, D. S. (2009). Problems and prospects of commercial small and medium scale cocoa and oil palm production in Cross River State, Nigerian Journal of Applied Science Research, 5, 827-832.

Ukiwo, U. (2020). Nigeria's oil governance regime: Challenges and policies. In U. Ukiwo \& P. Mbabazi (Eds.) Oil wealth and development in Uganda and beyond: Opportunities, and challenges (pp. 309-329). Leuven University Press.

Usman, S. (2000). The Central Bank of Nigeria: Rural finance policies and the agricultural credit guarantee fund. In J. Ruotsi (Ed.), After the reforms: Which way forward for Central Banks in rural finance (pp. 56-61). African Rural and Agricultural Credit Association, Nairobi.

WCF. (2014). Cocoa market update. World Cocoa Foundation (WCF), Washington, DC.

Yu, B., \& Nin-Pratt, A. (2011). Agricultural productivity and policies in Sub-Saharan Africa. IFPRI Discussion Paper 01150, December 2011, International Food Policy Research Institute, Washington, DC., USA.

Zadawa, A. N., \& Omran, A. (2020). Rural Development in Africa: Challenges and Opportunities. In Sustaining our Environment for Better Future (pp. 33-42). Springer, Singapore.

Zakaree, S. S. (2014). Impact of Agricultural Credit Guarantee Scheme Fund (ACGSF) on Domestic Food Supply in Nigeria. British Journal of Economics, Management \& Trade, 4(8), 1273-1284. 